\title{
Coastal Evolution, Hydrothermal Migration Pathways and Soft Deformation along the Campania Continental Shelf (Southern Tyrrhenian Sea): Insights from High-Resolution Seismic Profiles
}

\author{
Martina Misuraca, Francesca Budillon *, Renato Tonielli, Gabriella Di Martino, Sara Innangi \\ and Luciana Ferraro (iD) \\ Istituto per l'Ambiente Marino Costiero (IAMC), National Research Council of Italy, 80133 Naples, Italy; \\ martina.misuraca@iamc.cnr.it (M.M.); renato.tonielli@cnr.it (R.T.); gabriella.dimartino@cnr.it (G.D.M.); \\ sara.innangi@cnr.it (S.I.); luciana.ferraro@iamc.cnr.it (L.F.) \\ * Correspondence: francesca.budillon@cnr.it; Tel.: +39-081-542-3839
}

Received: 17 October 2017; Accepted: 21 March 2018; Published: 4 April 2018

\begin{abstract}
A closely spaced set of high-resolution Chirp-Sonar and Sparker profiles and swath bathymetric data was acquired in 2013 for the I-AMICA Project off the Volturno River mouth (Southern Tyrrhenian Sea) by the Istituto per l'Ambiente Marino Costiero (IAMC), National Research Council of Italy (CNR). The palaeo-topography of three key surfaces, represented by the bounding surfaces of the post-glacial lithosomes, was mapped by the interpolation of seismically detected reflectors. The morphology of the surface related to the Last Glacial Maximum (LGM) regression revealed the presence of fault linkages which defined a small-scale accommodation zone with an E-W trending interbasinal relative high. The observed set of oppositely dipping faults, NNWand ENE-directed, locally controlled the deposition of the paralic/deltaic bodies during the post-glacial rise in sea level, as testified by their wedge-shaped geometries and shifting depocentres. The deformation may be linked to the Campi Flegrei caldera collapse following the Neapolitan Yellow Tuff (NYT) eruption and aged $15 \mathrm{ka}$ BP. The relevant thickness of the Transgressive System Tract (TST) testifies to an increased sediment yield and intense reworking in coastal areas, probably driven by the high volcanoclastic supply during volcanic paroxysm, almost coeval with the post-glacial transgression. Fluid escape features linked to an E-W striking fluid front at the outer shelf suggest the presence of an hydrothermal system controlled by the predominant direction of normal to oblique Quaternary-active faults and by lithologic discontinuities across the sedimentary pile.
\end{abstract}

Keywords: fluid venting features; extensional tectonics; Chirp-Sonar profile; Sparker profile; delta lobe avulsion; Gaeta Gulf; Late Neogene

\section{Introduction}

The stratigraphical architecture of continental shelf deposits reflects the morphodynamic activity of the offshore deltaic system, constituting an ideal laboratory to investigate the complex interplay among fluvial inputs, glacioeustatic fluctuations, and tectonics. Channel aggradation processes, local uplift, and inherited topographic features are often triggering factors for a delta lobe to avulse [1,2] and may be directly inferred from facies distribution, lateral extent, and thickness of the deltaic deposits. Furthermore, modern continental shelves offer the opportunity to observe and map the presence of gas in shallow water sediments [3-5]. Biogenic methane is frequently produced in deltaic areas where clay-rich sequences are supported with a constant supply of organic matter. Nevertheless, the presence 
of thermal fluids could also have an effect in decreasing methane solubility, allowing the formation of gas bubbles and fluid-venting structures [5].

In this paper, we present a high-resolution Chirp-Sonar and Sparker seismic dataset along the Campania continental margin to interpret avulsion processes, fluid venting features, and anomalous thickness of the Upper Pleistocene-Holocene transgressive lithosomes in a more comprehensive regional structural framework. A very large dataset, derived from subsurface exploration of the Campania and Latium margin performed in the past decades [6-9], may serve as a stratigraphic reference for our purposes.

The strongly asymmetric Middle-Upper Pleistocene glacioeustatic fluctuations shaped the continental margins with slow and gradual sea level falling stages and by short-lived rise and highstand stages [10]. This usually resulted in forced regression and lowstand deposits characterized by coarsening upward parasequences stacking at the shelf margin and thin transgressive bodies with a gradual fining-upward trends, finally reaching a climax in a maximum flooding area [11]. Local variations in sediment supply and changing rates in sea level rise resulted in facies distribution and thickness variability [11-14]. Ground flow circulation patterns are related to permeability and deeply influenced by the stratigraphic context; accordingly, the variable grain size of the sedimentary pile at the shelf margin can coincide with sealing bodies or carrier beds. Therefore, the stacking pattern as well as the vertical and lateral variations of sediment textures distributions within the depositional sequences can deeply influence the configuration of migration pathways. Additionally, structural discontinuities can also act as preferred migration pathways, mechanical barriers, or mixed systems $[15,16]$. Thus, such physical discontinuities may affect the diffusion of a geothermal system and control its geometric configuration $[17,18]$.

On the basis of the geometric pattern of the structures composing the system, a recent classification of rising fluid types [19] resolved three different categories of features related to: (1) focused vertical fluid flow; (2) sediment remobilization processes; and (3) laterally extensive fluid flow. The most common seismic expressions of fluid escape features are pockmarks and pipe structures: columnar zones of vertically stacked, downward-bending reflections [20] which could be interpreted as collapse structures induced by the hydraulic fracture and fluid-driven erosion in conditions of high pore fluid pressure. These fluid venting structures, induced by focused vertical fluid flow, are very good timing indicators as they constrain the expulsion process to the reflection on which they occur [21]. Laterally extensive fronts of acoustic turbidity may be related to fluid accumulation zones occurring in certain stratigraphic intervals or at certain depths. Fluid front morphologies have also been explained as related to pressure and bottom water temperature [3] or to sedimentary facies association and permeability [22]. An accurate description of the fluid front morphologies is a fundamental tool to unravel the origin of the observed venting structures in order to better understand the late Quaternary evolution of the Campania margin.

\section{Geologic Framework}

The area under investigation is located along the Northern Campania shelf, off the Volturno coastal plain (Figure 1). The late Quaternary succession is characterized by prograding clinostratified deposits, truncated by the youngest Oxygen Isotopic Stage 2 (OIS 2)-related unconformity, recording multiple events from the subaerial exposure of the shelf to the successive sea level rise [6,23]. Records of the latest sea level rise, which occurred from $18 \mathrm{ka} \mathrm{BP}$ to $5 \mathrm{ka}$, as well as the present highstand conditions describe the transgressive and highstand deposits constituting a sedimentary wedge decreasing in thickness towards the shelf edge [24-26]. The proximity of the Volturno alluvial plain as well as the Campi Flegrei and Roccamonfina volcanic districts, respectively responsible for clastic and volcaniclastic sedimentary inputs, deeply controlled the Plio-Quaternary stratigraphic succession [27,28]. The Middle-Upper Pleistocene glacioeustatic fluctuations were characterized by high frequency (20-100 ka) and high amplitude, ranging from $+10 \mathrm{~m}$ to $-120 \mathrm{~m}$ [29]. Such variations occurred in the same depth range, leading to the erosion of the deposits related to a previous cycle during a sea level fall. The total 
subsidence enabled the preservation of deposits, acting as a key factor to drive the growth of the margin [6]. Beginning in the Early Pleistocene, major NE-SW striking faults affected the Tyrrhenian sector of the Campania region with vertical slip rate values of $4.3 \mathrm{~mm} /$ year [30], individuating highly subsiding and asymmetrical half grabens [31-35]. Severe subsidence rates characterized this tectonic scenario in which NW-SE striking left-lateral transtensive faults were also active [35]. Records of the Early-Middle Pleistocene horizontal throws have been reported on NW-SE left-lateral strike-slip faults in the Cilento region [34] and in the Sorrento area [35]. A Middle Pleistocene (0.7-0.4 Ma) tectonic event has also been reported in the Naples Gulf [30,36,37], with the presence of major NE striking normal listric faults. Since the late Quaternary, the onset of a tectonic event with a NE-SW oriented $\sigma 3[35]$ produced NW-SE normal faults with vertical offsets of a few tens of meters, as observed in the Campania [38] and in the Sele Plains [39]. A post-0.4 Ma tectonic event was individuated in the Gaeta Gulf, reactivating previous NE- and NW-oriented structural planes and producing horizontal offsets on E-W striking faults [37,40]. The same striking faults, as observed in the offshore of Naples Gulf, controlled in extension the deposition of the 39 ka Campania Grey Tuff [41,42] and influenced the 12-9 ka transgressive unit $[30,43]$. Volcanic activity, ascribed to different districts and provinces (Roccamonfina, Campi Flegrei, Ischia Island, and Somma-Vesuvius), aligned on a NW-SE direction, has been controlled by the same orthogonal systems of deformations [44,45]. Records of the oldest volcanic cycle have been observed in the offshore sectors of the western group of the Pontine islands with products emplaced from 4.2 Ma to $1 \mathrm{Ma}$ ago [46]. Volcanism followed an eastward migration with records of activity constrained at $0.8-0.13 \mathrm{Ma}$ ago on the island of Ventotene and from $0.63 \mathrm{Ma}$ to $0.13 \mathrm{Ma}$ to the Roccamonfina volcano [47]. A southeastward migration of volcanic activity was also observed and revealed by the presence of several buried volcanic structures off the Southern Gaeta Gulf, Ischia, Campi Flegrei, and Naples areas, respectively emplaced from the Early to Upper Pleistocene [48]. The Campi Flegrei volcanic district, ascribed to the latest tectonic and magmatic event, deeply influenced the evolution and geomorphological setting of the study area. Its structure is the result of two distinct caldera collapses originating, respectively, from major eruptions and pyroclastic currents: the Campanian Grey Tuff (CGT) at about 39 ka [42,49] and the Neapolitan Yellow Tuff (NYT), dating to ca. $15 \mathrm{ka}[41,50]$. 


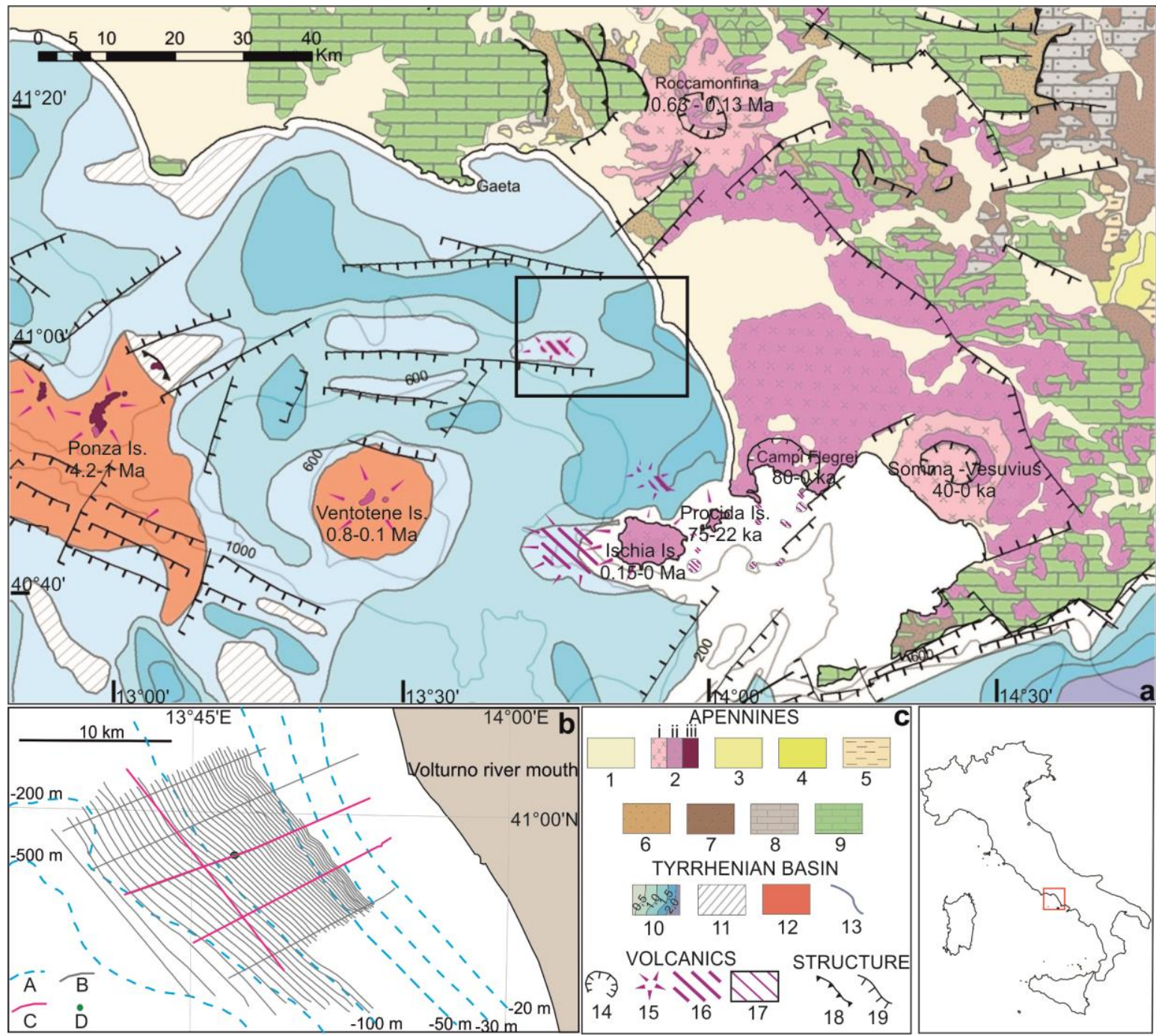

Figure 1. (a) Synthetic geological scheme of the inner sectors of northern Campania-Southern Latium (redrawn from the "Structural model of Italy" [51]); the black box marks the study area; (b) geophysical survey grid acquired by the IAMC-CNR of Naples during the I-AMICA Project in 2013; (A) bathymetric contour (by Istituto Idrografico della Marina nautical map), (B) Chirp-Sonar profile, (C) Sparker profile, (D) C5 core site; and (c) (1) Quaternary deposit; (2) potassic volcanics, Upper Pliocene-Pleistocene: (i) undersaturated, (ii) intermediate, (iii) acidic composition; (3) Upper Pliocene-Lower Pleistocene conglomeratic body (Conglomerati di Minturno Auct); (4) Pliocene deposit (5) Messinian deposit; (6) Foredeep deposit, Upper Tortonian; (7) flysch unit, Post-Burdigalian; (8) external Sicilide Unit; (9) Apenninic carbonate units (10) thickness of the Plio-Quaternary cover; (11) undifferentiated substratum; (12) volcanic substratum; (13) isobath; (14) caldera rim; (15) dome; (16) buried magmatic body [30]; (17) outcropping magmatic body; (18) main thrust front; and (19) main normal fault.

\section{Methods and Dataset}

The geophysical acquisition included a swath bathymetric and shallow high resolution (HR) single-channel seismic (Chirp-Sonar and Sparker) survey performed by the IAMC-CNR of Naples during the oceanic cruise I-AMICA 2013, on board the R/V “Urania” [52]. Bathymetric data acquisition was carried out with the use of the Kongsberg Maritime AS (NOR) EM710 multibeam echosounder system. The system was keel mounted and interfaced with a Differential Global Positioning System. Positioning and attitude data were corrected during acquisition. A sound velocity probe was installed near the transducers providing the real-time sound speed for the beam steering, while a sound velocity 
profiler was used to record the property of the water column every $6-8 \mathrm{~h}$ in order to obtain the velocity profile required for accurate beam forming [53]. The whole dataset covers a surface area of $270 \mathrm{~km}^{2}$ in a depth range 16-500 $\mathrm{m}$ (Figure 2). The data were acquired using the interface Seafloor Information System (SIS) software and were processed using Hips and Sips 7.0.2 by Teledyne CARIS, Inc. (Fredericton, NB, Canada). Data were then used to produce a high-resolution digital terrain model (DTM) with a $5 \mathrm{~m}$ grid cell size (Figure 2).

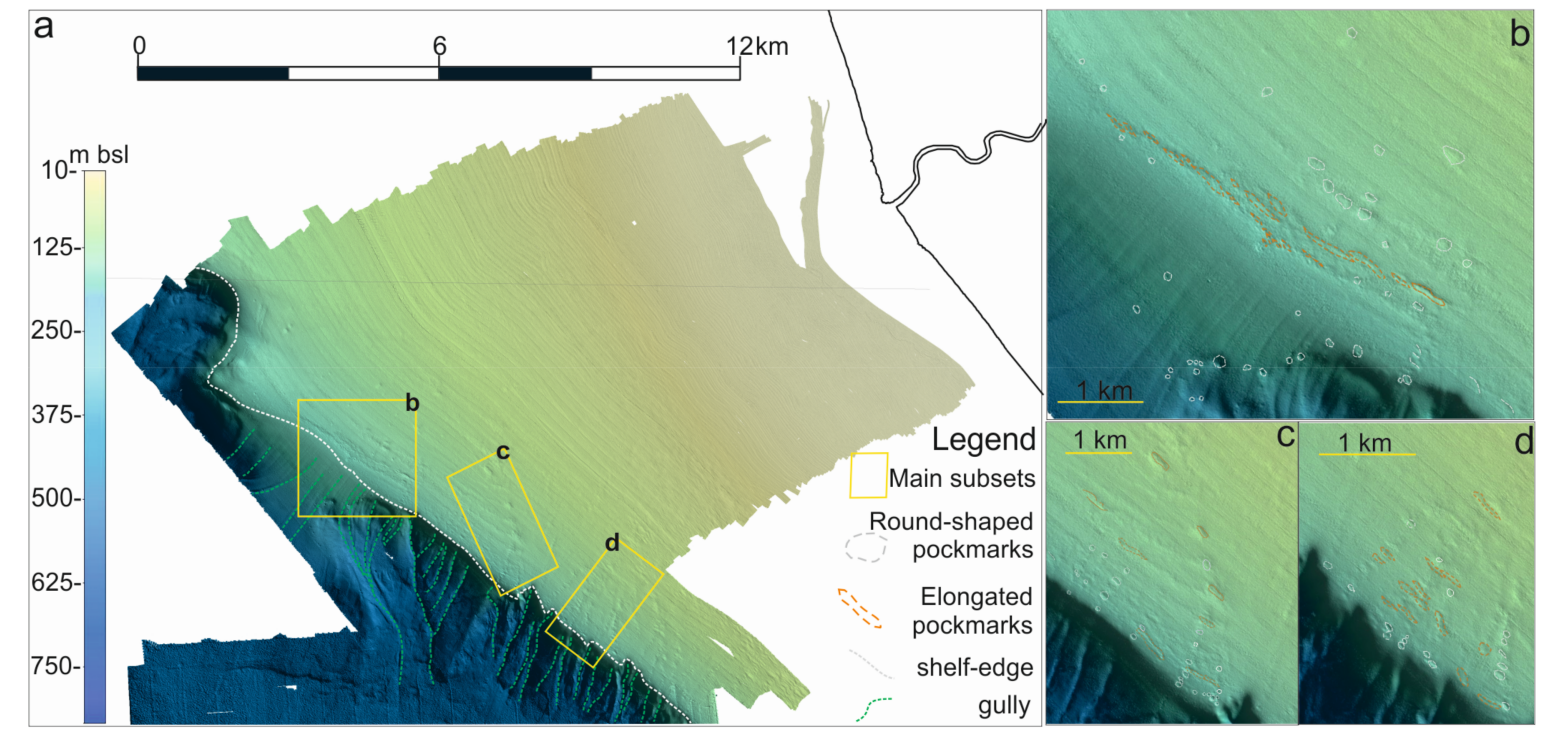

Figure 2. (a) Digital terrain model off the Volturno River: b, c, d boxes refer to the location of different subsets; (b-d) details of the round-shaped or elongated depressions detected the shelf-edge and marking the sites of fluid seapages; diameter sizes range between 30 and $70 \mathrm{~m}$ for the rounded features and 200-300 $\mathrm{m}$ for the elongated features.

A high-resolution morpho-bathymetric map of the seafloor, covering the continental shelf off the Volturno river mouth and the uppermost sector of the slope, provided a fundamental tool to identify different classes of fluid escape features. A 1-kJ Sparker power supply with a multitip Sparker array by Geo-Resources BV (NLD) was used as a seismic source with a frequency of about $800 \mathrm{~Hz}$, fired at a time interval of $1 \mathrm{~s}$. Data were recorded using a single-channel streamer and Triton SB-L 7.2 software by Smartsea Technology Co., Ltd. (Wuxi, China) and processed by the GeoSuite Allworks software by Geo Marine Survey Systems (NLD), by applying an IIR filter, amplitude gain control, signature deconvolution, swell filter, time-variant gain, and muting of the water column; signal penetration exceeds $300 \mathrm{~ms}$ t.w.t. and the vertical resolution is $\sim 2 \mathrm{~m}$ just beneath the seafloor. A densely spaced net of ultra-high-resolution seismic data was also recorded using the hull mounted mod. CAP-6600 Chirp-Sonar III Profiling System by Teledyne Benthos Inc. (Shingle Springs, CA, USA), operating with 16 transducers in the $2-7 \mathrm{kHz}$ wide frequency band and with a $10-20 \mathrm{~ms}$ pulse length. A number of about 60 Chirp-Sonar profiles were logged at the same time as the swath-bathymetric data (Figure 1b). Given the densely spaced net of profiles, a 3D-like reconstruction of the seismically detected horizons ensued.

The uppermost $5 \mathrm{~m}$ of the $7 \mathrm{~m}$-long core $\mathrm{C} 5$ recovered on the outer shelf (location in Figure $1 \mathrm{~b}$, $40^{\circ} 58^{\prime} 24.953^{\prime \prime} \mathrm{N}, 13^{\circ} 47^{\prime} 02.514^{\prime \prime} \mathrm{E}, 93 \mathrm{~m}$ below sea level, b.s.l.), represent the only tool for calibrating the seismics. Stratigraphic and magnetic susceptibility analysis in the first $5 \mathrm{~m}$ [54] enabled seismic calibration of the shallowest seismic horizons (Figure 3).

Data on the Late Quaternary outbuilding of the margin and the analogies of the geometries of deep unconformities, interpreted by previous authors along the Latium and Campania continental shelf $[6,27,37,48]$, provided a guide for the interpretation of Sparker profiles (Table 1). 


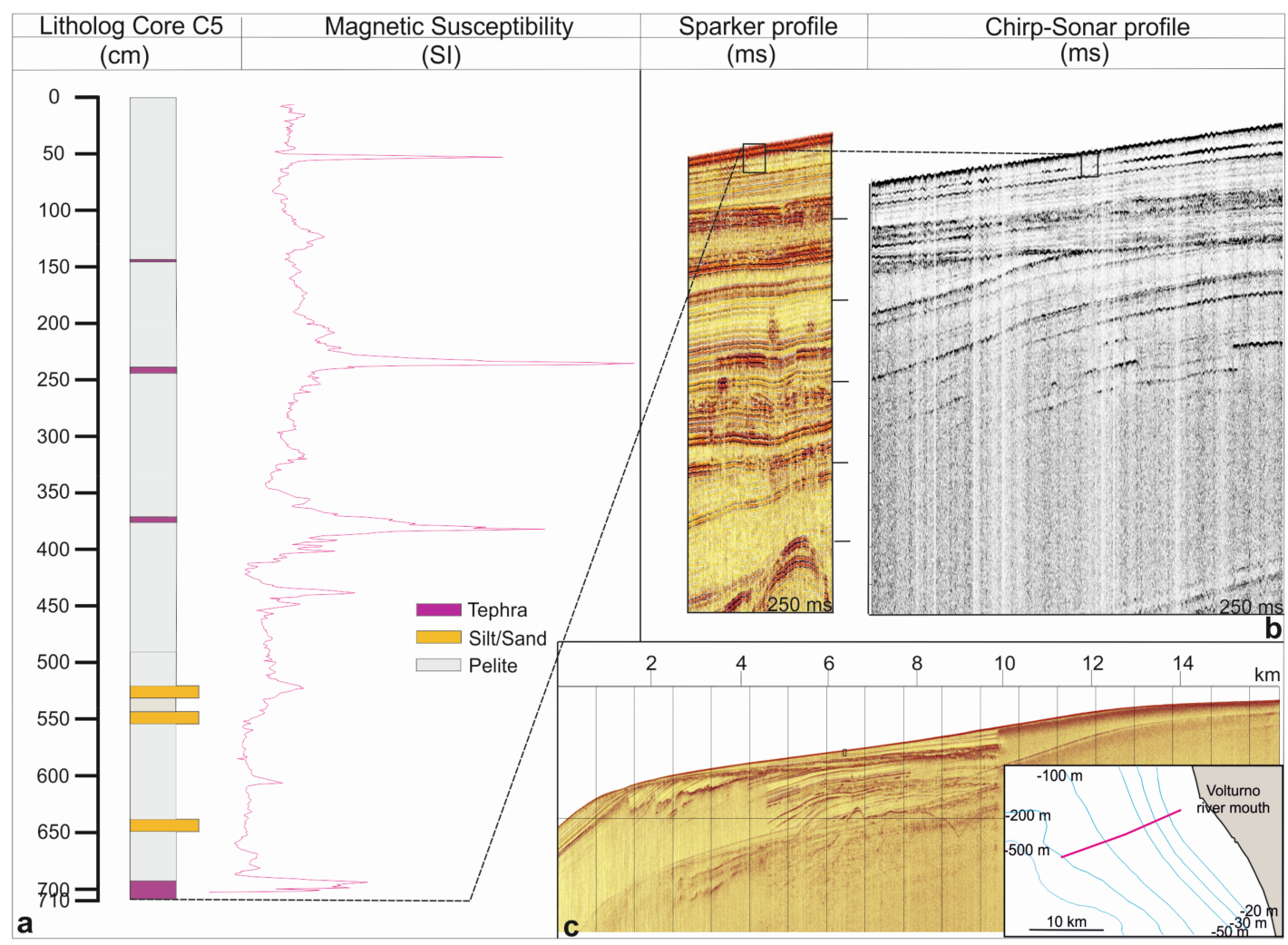

Figure 3. (a) Stratigraphy and magnetic susceptibility curve of the C5 core (redrawn from [54]); (b) seismic facies calibration; and (c) the location on seismic section SP1 of the deepest stratigraphic horizon intercepted by the core.

Table 1. Calibration of U1-U9 seismic units according to A. Milia et al. and G. Margaritelli et al. [37,54].

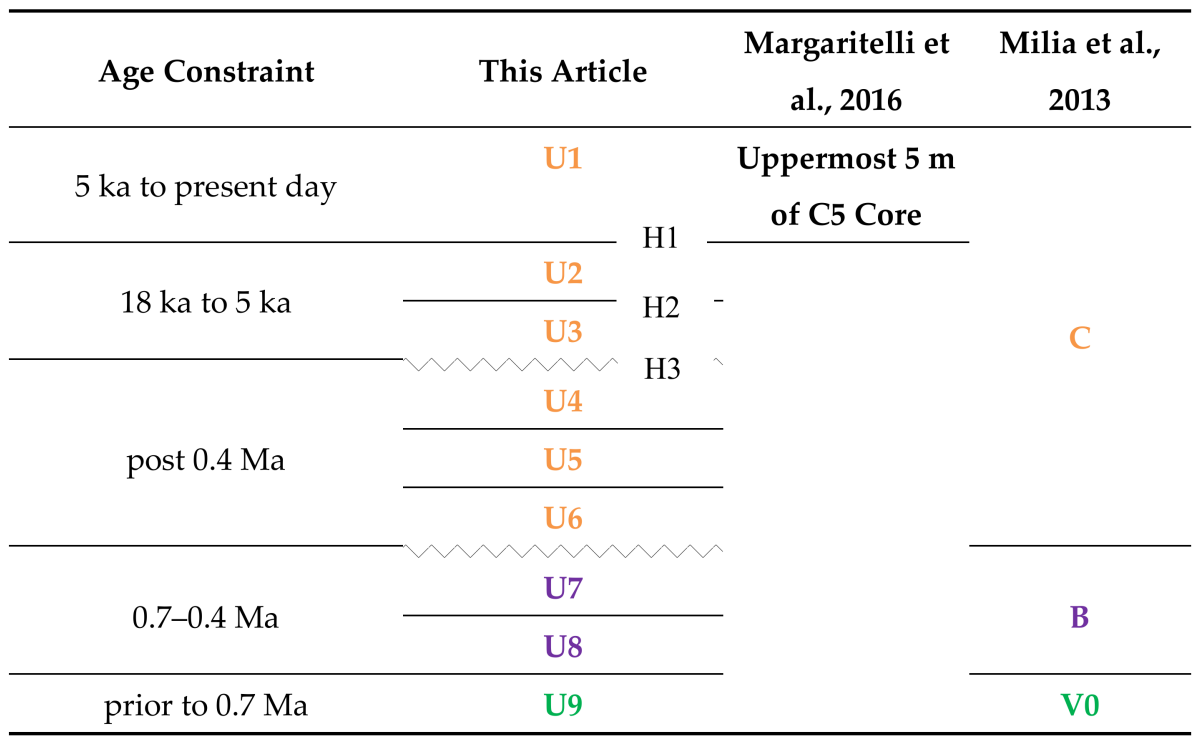

\section{Results}

\subsection{Seafloor Morphology}

A variety of structures were displayed by the DTM obtained by the multibeam bathymetric survey (Figure 2). In the inner shelf, a pronounced break in slope at $-25 \mathrm{~m}$ marked the transition from topset-to-foreset rollover depth of the subaqueous delta [55]. The transition between the shelf, 
gently deepening seawards, and the continental slope occurred at $-150 \mathrm{~m}$ depth, where the shelf break was located. The slope area exhibited an uneven topography with several submarine gullies and landslide scars [56]. Most of the seabed features were located along a WNW-ESE orientation and were represented by pockmarks and elongated steps, with a direction strikingly parallel to the isobaths. However, two classes of seabed depressions were detected: sub-circular/elliptical and elongated ones. Most of the sub-circular craters had smaller dimensions with the diameter size ranging between $30 \mathrm{~m}$ to $70 \mathrm{~m}$ and were aligned in a NE-SW trending direction. The elongated craters, displaying a bigger diameter, exceeded 200-300 m along their longest axis, and were aligned in a NW-SE direction. Long alignment of such clusters corresponded to areas of coalescent pockmarks, which created a morphological step, evident both on the DTM and seismic profile (Figure 2b).

\subsection{Seismic-Stratigraphic Surfaces and Units Derived from Chirp-Sonar Profiles}

The densely spaced seismic lines collected during the bathymetric survey provided the high coverage necessary to realize 3D-like maps of the most relevant seismically detected horizons. Three main reflectors, bounding four major seismic units, have been mapped, which, top to bottom, are H1, $\mathrm{H} 2$, and $\mathrm{H} 3$ (Figure 4). A seismically transparent body constituting Unit 1 (U1), displayed an aggrading stacking pattern and downlap terminations. Its thickness decreases towards the shelf break in an external wedge-shaped configuration. This unit displays cylindrical reflection anomalies, constituted by a series of vertically stacked depressions affecting the unit up to the seabed (Figure 5). A clearly recognizable high-amplitude reflector (H1 horizon) separates U1 from the unit underneath (Unit 2, U2). Medium to low amplitude sub-parallel and aggrading reflections characterize this unit, displaying downlap terminations above a highly irregular reflector ( $\mathrm{H} 2$ horizon). Occasionally patchy and wavy high-amplitude reflectors, which were enclosed in lenses and arranged in a backstepping external configuration, characterize Unit 3 (U3, Figure 4).

Unit 3 is wedge-shaped, with thickness increasing in the landward direction, reaching values up to $10 \mathrm{~ms}$ and revealing a sedimentation controlled, in some cases, by normal faulting (Figure 5). Bounding at the bottom Unit 3 (U3), reflector H3 has a highly irregular trend and is characterized by a strong acoustic impedance contrast with the region beneath it in which the signal is not always penetrating.

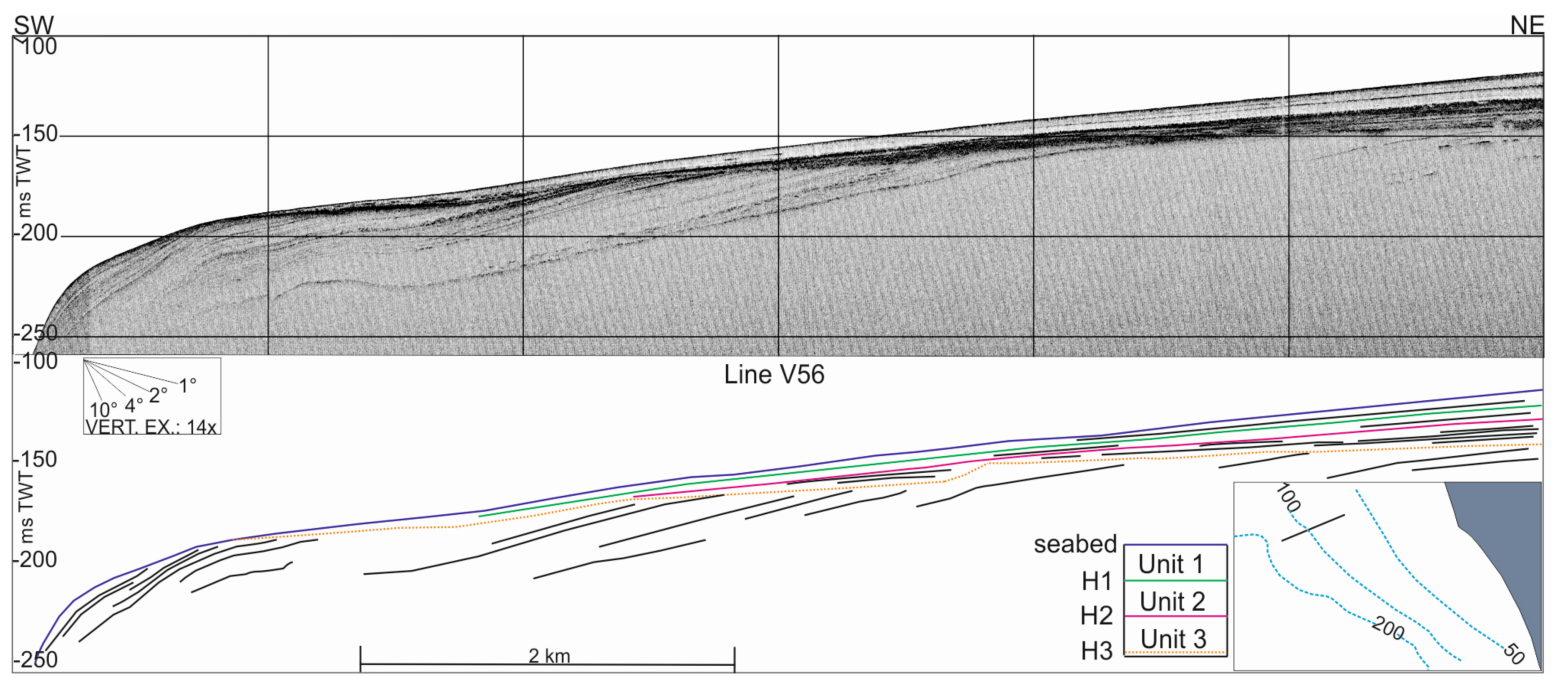

Figure 4. Three main horizons (H1, H2, and H3) were seismically detected on Chirp-Sonar profiles and mapped. They bound Unit 1, Unit 2, and Unit 3, related to the post-glacial deposition on the shelf.

The recognized pattern of faults, controlling the deposition of Unit 3 and cutting also the uppermost seismic units, is composed by NW-dipping normal faults, observed in the northern side of the studied area, forming a downthrown region in a tilted block configuration (Figure 5). In the 
southeastern side of the studied area, ENE-WSW trending, SE-dipping normal faults defined a relative morphological low. An interbasinal relative high, with a roughly trending $\mathrm{E}-\mathrm{W}$ direction, defined by two outward-facing normal faults, separated these two topographic lows.

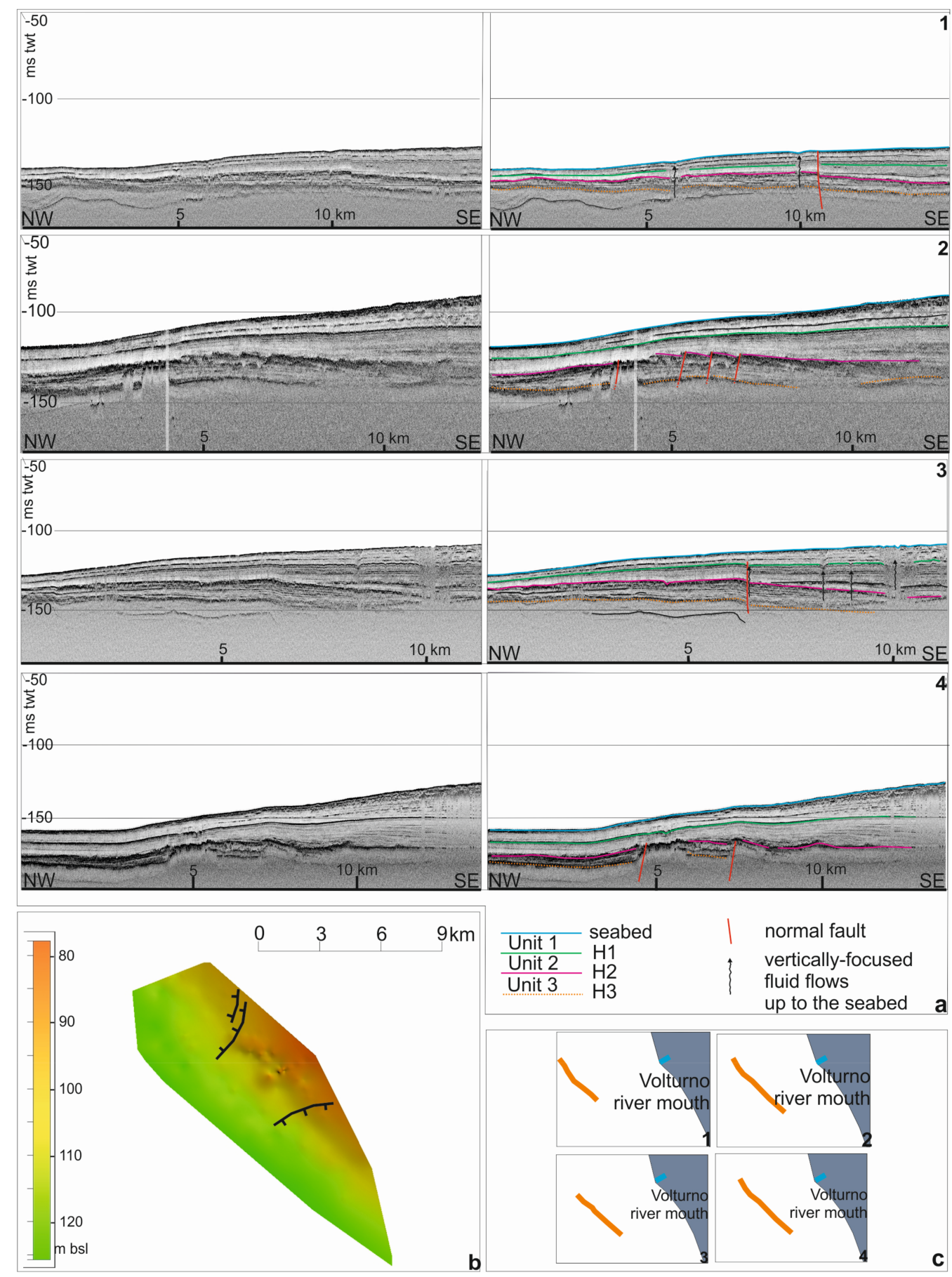

Figure 5. (a) Four Chirp-Sonar profiles $(1,2,3,4)$ revealed the presence of NW dipping normal faults on the northern side of the interpreted grid, forming a downthrown region in a tilted block configuration. In the southeastern side of the grid, trending ENE-WSW, SE-dipping normal faults defined a relative morphological low; disrupted reflectors and columnar zones of acoustic masking depicted the sites of vertically focused fluid flows reaching the seabed and correspond to pockmarks (1 and 3); (b) 3D-like modelling of the $\mathrm{H} 3$ erosional surface revealed the presence of a relative high, bounded by two sets of outward-facing faults of limited offsets; and (c) the location of the interpreted profiles. 
The 3-D-like modelling of $\mathrm{H} 1, \mathrm{H} 2$, and $\mathrm{H} 3$ surfaces, evidenced two NE-SW-elongated depocentres of U3 unit, separated by a relative topographic high and a NE-SW-elongated depocentre of U2 unit, slightly shifted southwards (see Section 5.5).

\subsection{The Stacking Pattern of the Seismic Units by the Sparker Profiles}

Nine seismic units have been recognized on Sparker sections (Figure 6), of which the uppermost three correspond to those identified in the Chirp-Sonar profiles. Downlap terminations of the wedge-shaped unit (U1), characterized by low amplitude reflections, rest on the high-amplitude reflector (H1). Below it, low-amplitude subparallel reflections display downlap terminations above the undulating and irregular reflector $\mathrm{H} 2$. Wavy and high-amplitude reflectors lie below $\mathrm{H} 2$ and describe the lenticular bodies piled in a retrograding (backstepping) external configuration, with a thickness increasing in a landward direction (U3), exceeding $10 \mathrm{~ms}$. A flat and gently seaward deepening reflector $(\mathrm{H} 3)$ cuts, on the observed profiles, almost all the units underneath, producing toplap terminations and erosive truncations on the mostly below and laterally stacked U4, U5, U6, U7, and U8 seismic units. An upslope thinning unit (U4) was observed beyond the shelf break, exhibiting clear onlap terminations above the $\mathrm{H} 4$ reflector. Oblique parallel progradings characterize unit U5, passing laterally across a generally concordant $\mathrm{H} 5$ reflector to unit $\mathrm{U6}$, displaying an external sigmoidal geometry. The migration of offlap breaks indicates, at the base, an aggradational pattern, then a marked progradational progression of the roll-over points with a decrease in acoustic transparency moving up the section. The H6 reflector marks the transition to the unit U7 with an external tabular configuration and a stratified aggradational to a progradational growth patterns, moving upwards. Unit U7 onlaps on the $\mathrm{H7}$ reflector which represents a major erosional unconformity, gently dipping in a seaward direction. Below H7, unit U8 displays a prevalent aggrading migration of the offlap breaks and upper toplap terminations. This unit shows onlap terminations against the $\mathrm{H} 8$ reflector and a variable thickness among reflections, suggesting possible syndepositional ground movements. The unit U9, the lowermost detected unit, corresponds to a transparent acoustic body with a mound-shaped external form (Figure 6), extending in an E-W trending direction (see Section 5.4).

Laterally extensive pockets of amplitude anomalies have been observed on seismic profiles in the inner and outer shelf.

The seismic expression of the outer shelf pocket was an intermittent acoustic turbidity, alternated to columnar zones of amplitude masking, marked at the top by high amplitude disrupted reflectors, arranged in a saw-toothed top profile (Figures 6 and 7). The top boundary of the acoustic anomaly, ranging from 0.18 to $0.27 \mathrm{~ms}$ b.s.l., did not pertain to a specific stratigraphic horizon, but tracked several horizons of units U5, U6, and U7 (Figures 6 and 7). Accordingly, the acoustic turbidity front depicts intermittent and sharp lateral flanks and an irregular and gradual top front. In plan view, it is roughly E-W oriented over an approximate area of $40 \mathrm{~km}^{2}$.

In the inner portions of the shelf (Figure 6) a wide zone of acoustic signal wipe-out was also observed. Here, the acoustic blanking was complete, right below a stratigraphic reflector of U1 (Figure 6A). The shape of the front was sub-circular in plan view, almost centred at the Volturno River mouth (Figure 6C).

Distinct sites of vertically focused flows, marked by columnar zones of amplitude masking and disrupted reflectors, reached the seabed at the outer shelf and corresponded to craters (Figures $5 \mathrm{a}$ and $7 \mathrm{~b}$ ). Locally, long alignments of seepages, likely of long existence, have been inhibiting the deposition of sediments of the highstand wedge, creating a non-deposition area. This non-deposition area corresponded to the alignment of elongated pockmarks (Figure 2b) and accounted for the creation of a minor morphological step at the seabed (Figure $7 \mathrm{~b}$ ). 


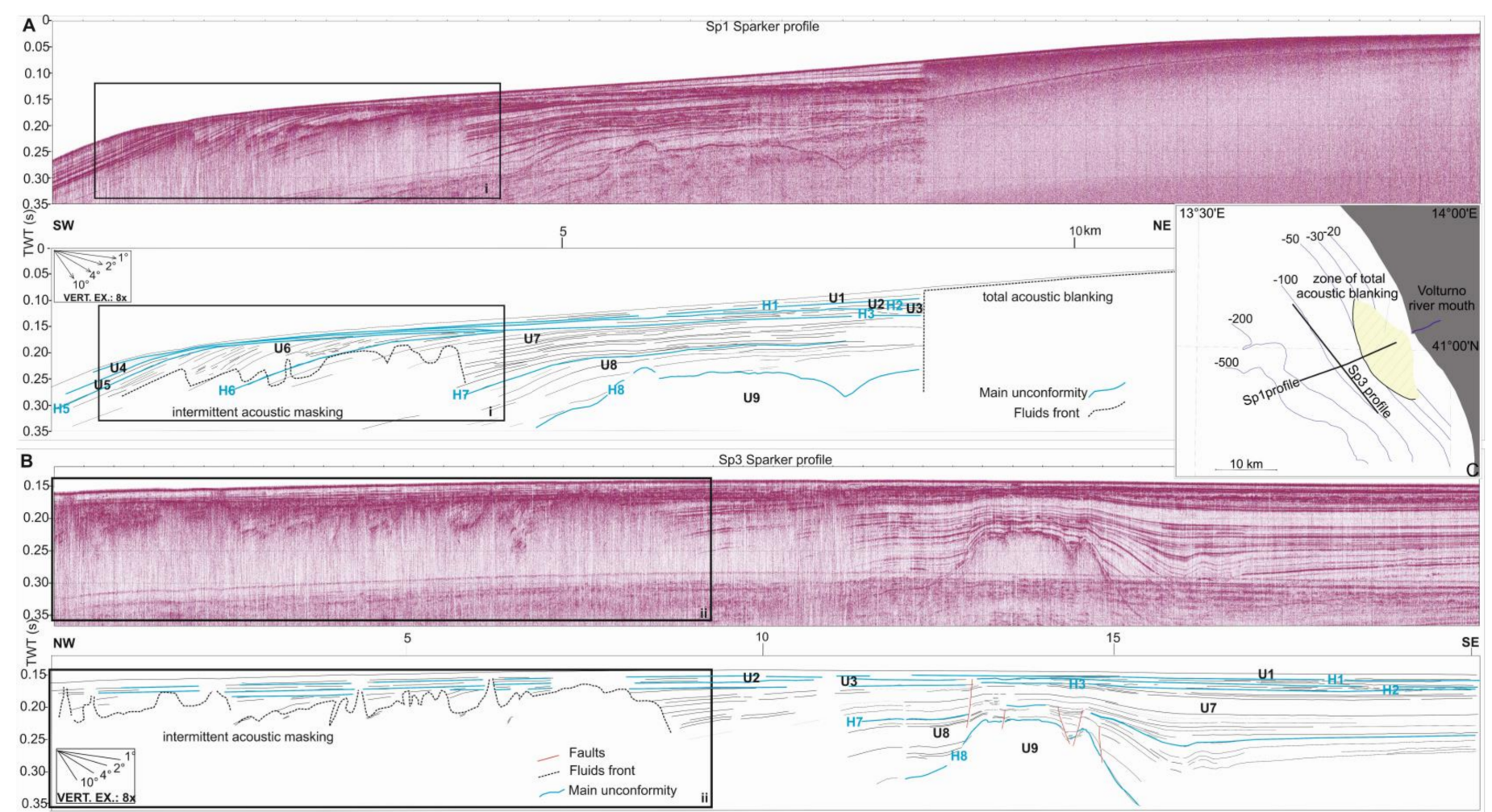

Figure 6. (A) The Sp1 Sparker profile shows the stacking pattern of the nine uppermost seismic units of the continental margin and the zone of the inner shelf with shallow gas (total acoustic blanking); Frame i marks the detail of the intermittent acoustic masking zone and the location of its saw-toothed top profile, shown in Figure 9; (B) the Sp3 Sparker profile shows nine seismic units and the peculiar top profile of the acoustic turbidity front, which develops for about $10 \mathrm{~km}$, striking the coast; Frame ii marks the detail of the acoustic turbidity zone, shown in Figure 9; and (C) the zone of total acoustic blanking is semi-circular in plan view and centred at the Volturno River mouth. 


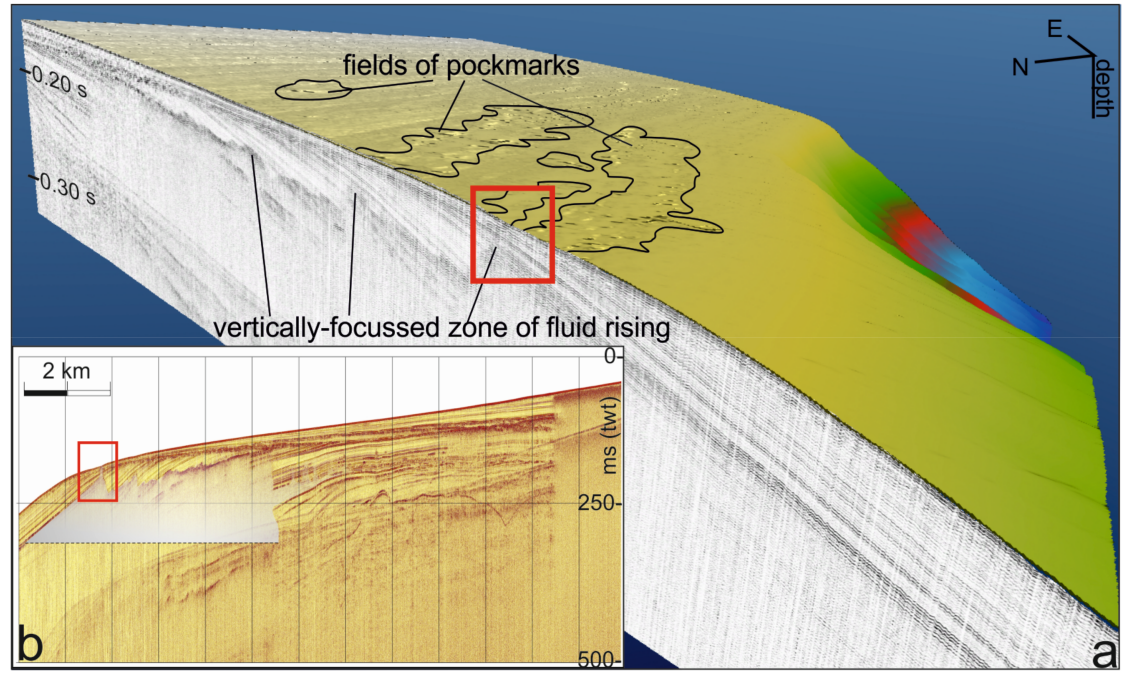

Figure 7. (a) The vertically focused zones of rising fluids corresponded to extensive fields of pockmarks at the seabed. The top profile of the pocket developed as a saw-toothed configuration, probably related to vertical and lateral variations in permeability of the sequences, composing the succession; and (b) the detail of the acoustic turbidity front (location in Figure 6, Frame i); the red box evidences the locus of a vertically focused flow, possibly active as a seepage up to recent times, inhibiting the deposition of late Holocene sediments and resulting in a morphological step (see also Figure 2b).

\section{Discussion}

\subsection{Calibration of Seismic Sections: The Stratigraphic Framework}

Literature data [54] reported stratigraphic and magnetic susceptibility analyses performed on the C5 core (Figure 3), recovered on the outer shelf, immediately offshore of the Volturno River mouth at $93 \mathrm{~m}$ b.s.l. Top to bottom, a dominant pelitic succession characterizes the first $5 \mathrm{~m}$, interbedded with five major tephritic layers, identified by peaks in the magnetic susceptibility record, geochemical, and micropaleontological analysis performed on the $>63 \mu \mathrm{m}$ fractions [54]. Coarser-grained deposits with thin sandy intercalations characterized the lowermost two metres at the base of the C 5 core.

The hemipelagic succession recovered by the first $5 \mathrm{~m}$ of the core recorded a time span of $5 \mathrm{ky}$, proven by the correlation of tephritic layers to well-known eruptions from the Campi Flegrei and Somma Vesuvius districts. The C5 recorded part of the succession, interpreted as the present-day highstand muddy sequence, calibrated the topmost unit U1 made of low amplitude reflections. Below it, deposits related to the latest sea level rise, occurring from $18 \mathrm{ka} \mathrm{BP}$ to $5 \mathrm{ka} \mathrm{BP} \mathrm{[23-26]-} \mathrm{or} 18 \mathrm{ka}$ to $7 \mathrm{ka}$ according to [57]- correspond to distinctive marine and paralic facies associations of units U2 and U3, respectively. Patchy, high-amplitude, and retrograding acoustic bodies, constituting Unit 3 at the base of the transgressive intervals (Figure 5a), should include coarse-grained deposits [58]. Such bodies, recovered on the mid-shelf, should have settled in a coastal environment, consistent with the position of the sea level at about $-80 \mathrm{~m}$, some $14 \mathrm{ka}$ BP [59]. Above it, a more distal facies association (U2) testified to the landward migration of the coast. This interpretation of units U2 and U3 matches with the well-acknowledged stratigraphic significance of the $\mathrm{H} 3$ reflector at the Mediterranean scale as the Last Glacial Maximum (LGM) erosional surface, recording multiple time-transgressive morpho-evolutive processes ranging from the progressive exposure of the shelf, due to the sea level drop, to the following post-glacial sea level rise ([6] and references therein).

Recent studies $[7,28]$ contributed to the definition of a very thick transgressive systems tract (TST), individuating and calibrating in the upper slope area off the Campi Flegrei area the seismic evidence of the NYT $[41,50]$. This tephra has been found below the maximum flooding surface, confirming that the deposits bounded by this major tephritic layer and the LGM erosional surface can be ascribed to an early stage of the transgressive systems tract. 
Lacking any possibility of direct ground truthing, the calibration of deeper horizons identified on the Sparker section can be attempted by analogies in geometrical characteristics of reflectors with other profiles acquired along the central Tyrrhenian margin (Table 1).

Volcanic buried bodies and four different unconformity-bounded units (PP, A, B, and C, respectively), constituting the Plio-Quaternary record, have been recognized off Gaeta Bay [37]. In particular, we refer to a major E-W trending structure recognized by the authors offshore of the Volturno River mouth, a volcanic edifice in place prior to $0.7 \mathrm{Ma}$ [60], showing coastal onlaps of the above lying sequences. We have correlated the U9 unit with the well-known V0 Lower Pleistocene volcano [37]. Following the interpretation of the authors, the U8 seismic unit should have corresponded to one of the sequences composing the third-order unconformity-bounded unit B (0.7-0.4 Ma), revealing coastal onlap on the described volcanic edifice at about 0.3 twt. This major unit was constituted by sigmoidal prograding sequences with significant aggradation processes. This was consistent with U8 and the lowermost part of the U7 seismic units, which showed the same geometric pattern. Starting from the uppermost part of U7 seismic unit, an oblique parallel clinoform geometry and the largely lateral stacking of sequences testified to a stricter progradational pattern. We correlated this succession to the unconformity-bounded unit C, i.e., the last major sequence composing the margin [37], recording a post- 0.4 Ma rapid landward shift of the offlap breaks. Thus, Sparker profiles recorded a Middle-Upper Pleistocene to Holocene succession.

\subsection{Structural Lineaments}

Normal faults cutting the transgressive and highstand units with very small offsets (ranging between 2 and $5 \mathrm{~m}$ ) were displayed by Chirp-Sonar profiles. The 3D-like modelling of the LGM erosional surface (Figure $5 b$ ) outlined a relative high, bounded by two sets of outward facing faults.

Extended domains are usually segmented in fault systems whose terminations and geometrical transitions have been extensively studied [61-65]. In this typically asymmetrical segmentation, fault linkages are generally ascribed to two main families of structures responsible for displacement transfer, known as accommodation and transfer zones [61]. Accommodation zones correspond to areas in which soft and distributed deformation occur at the overlapping fault terminations $[63,66,67]$. Hard-linkage processes, in response to an increased displacement, should be invoked for the formation of transfer zones, defined as areas of discrete deformations, with a very strong strike-slip component [61,64,68-70]. The observed deformations revealed a structural setting constituted by two opposite-facing sets of faults, separated by a relative topographic high located in the overstepping region (Figure 8). No strike-slip component has been seismically detected and the accommodation zone, individuated in the topographic relative high, had a slightly oblique orientation with respect to the NE-SW extension trending direction, revealed by the main NNW-SSE trending set of faults and reported in literature [33,35].

A general classification for accommodation zones is known [67] in which the antithetical ones have been further subdivided both on the basis of inward or outward facing faults and on the orientation of the transfer zone with respect to the regional $\sigma 3$. Following this classification the observed structure, although small-scaled and with minimal offsets, seems to correspond in the arrangement to an antithetic oblique synclinal accommodation zone. The activity of these faults appears to be constrained by the locally observed growth patterns in the interpreted paralic transgressive bodies (Figure 5a), whose deposition is referred to the initial stages of the last sea level rise which occurred from $18 \mathrm{ka}$ to $5 \mathrm{ka}$ BP [23-26]. Around $15 \mathrm{ka}$, the Campi Flegrei caldera was collapsing [50] in the onland area (Figure 1a), producing an important volcaniclastic aggradation and great volumes of pyroclastic deposits. Such a dramatic event should have influenced and perturbed the stress field distribution, accommodated in the study area by the reconstructed structure.

\subsection{Degassing Features}

The high-resolution bathymetry depicts the presence of two classes of pockmarks: elliptical and elongated, showing a NE and a NW trending direction, respectively (Figure 2). The NE-SW-oriented 
small-shaped class of pockmarks seems to match the direction of gullies in the slope area and the maximum dip incline of the shelf (Figure 2c,d) quite well. It is acknowledged that buried palaeo-channels and gullies, infilled with coarse-grained lithology which are more permeable than the muddy bulk of the continental margin, may constitute a preferred migration pathway for fluids [71,72]. Although no evidence of buried paleo-channels has emerged from the HR profiles parallel to the coasts, possibly due to a combination of low seismic signal penetration and noisy records, the coinciding orientation between gullies on the upper slope and the NE-SW-oriented pockmark on the shelf, lets us infer the occurrence of an undetected buried paleo-drainage system which may have favoured the vertical migration along such preferred paths.

The mapping of craters and depressions at the outer shelf suggests that the majority of them occur above the laterally extensive zones of acoustic anomalies or in their immediate vicinities. Vertical funnel-shaped and downward-tapering anomalies, interpreted as pipes, located immediately below the main detected pockmark field, are rooted in a deeper fluid pocket and have been individuated in the southeastern area of the interpreted grid. The morphology of the fluids' front depicts sharp and distinct lateral flanks, giving this pocket a WNW-ESE trending direction (Figure 9).

Thus, the second class of pockmarks seems to match the overall direction of the fluid front and coincides with distinct sites of vertically focused flows (Figure 7) quite well. Observations of the vertical sections show that the longest alignment of coalescent pockmarks (Figure 2b) among those NW-oriented locally corresponds to an abrupt closure of the wedge-shaped HST and to a 6-km long morphological step at the seabed (the red box in Figure 7b), localized at about $140 \mathrm{~m}$ b.s.l. Literature data [54] report a depositional rate of about $0.1 \mathrm{~cm} /$ year over the last $4.5 \mathrm{ka}$ at $93 \mathrm{~m}$ b.s.l. and the prevalence of fine-grained particles pertaining to an hemipelagic deposition. Therefore, a lower depositional rate can be inferred at the outer shelf where the morphological step occurs. Under these conditions, even a sporadic activity of fluid seeps could be effective in controlling the dispersal of fines and modify the shape of the HST pinch-out over time. Such coinciding features may prove an active venting process up to recent times, inhibiting the deposition of post-glacial fine sediments locally at the shelf edge.

The bulk of the laterally extensive fluid front has been individuated in the Upper Pleistocene prograding units. More coarse-grained sediments, in comparison with the Holocene highstand units, constitute the prograding sequences composing the margin. Such sediments could host fluidsproviding good conditions for their lateral migration [22]. The main trending direction of this front is similar to the one observed for the detected roughly E-W striking volcanic body, despite its location seems to have shifted southward (Figure 10). The acoustic masking zone's peculiar facies association, strikingly different in the acoustic response when compared to inner shelf observations yet similar in the trending direction of the volcanic body, suggests that these venting features could be related to buried magmatic bodies.

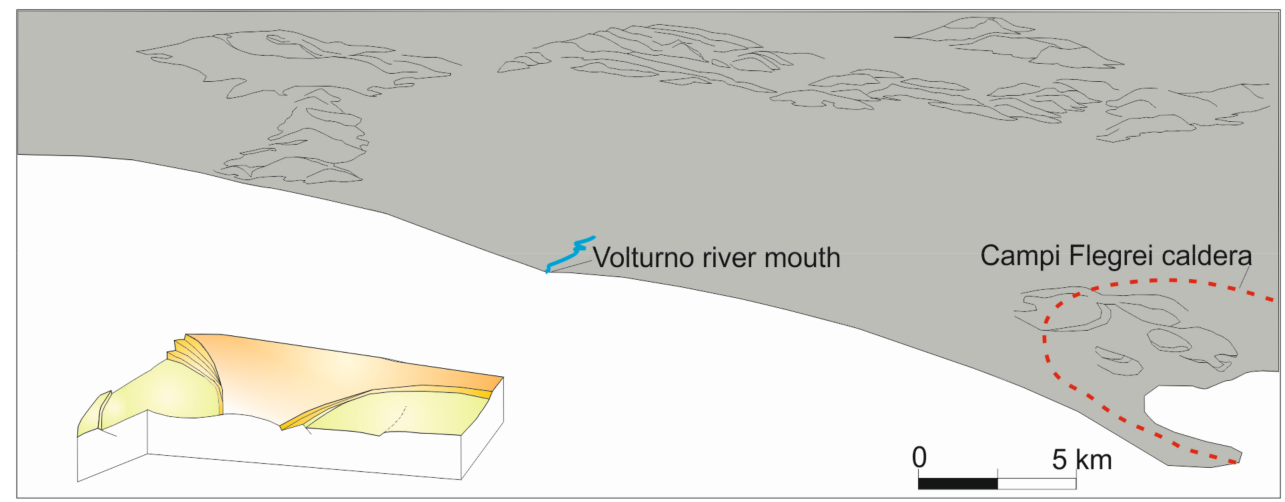

Figure 8. Block diagram of the $\mathrm{H} 3$ erosional surface deformed by two opposite facing set of faults, separated by a relative topographic high, located in the overstepping region (offsets not to scale). 


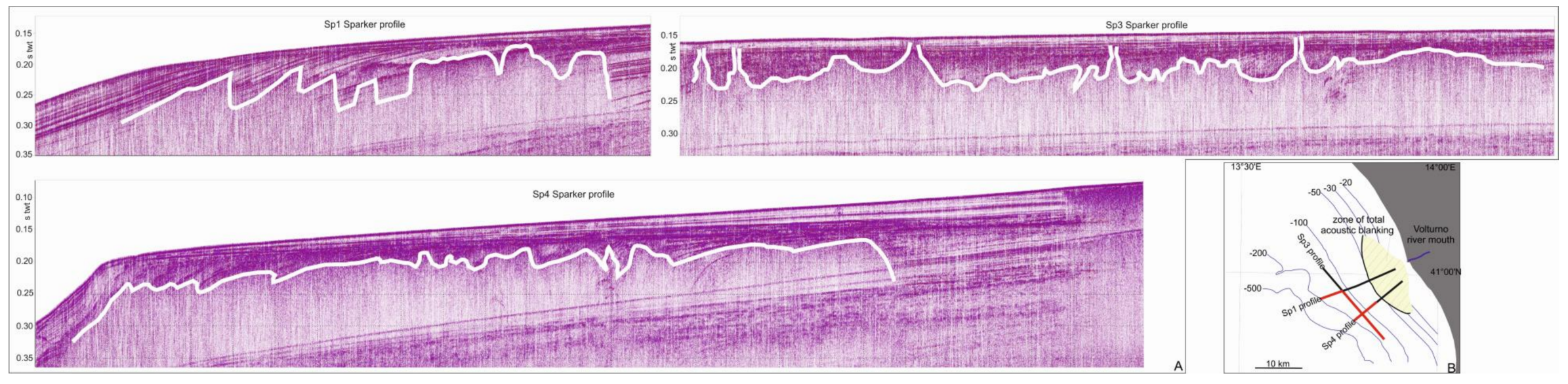

Figure 9. (A) Extension of the acoustic turbidity zone in Sparker lines (Sp1, Sp2 and Sp4) showing a remarkable shape of the top boundary, marked by enhanced acoustic reflections and intermittent acoustic masking; and (B) in dashed yellow is the lateral boundary of biogenic gas at the Volturno River mouth and, in red, the extension along the Sparker profiles of the inferred hydrothermal fluid front. 


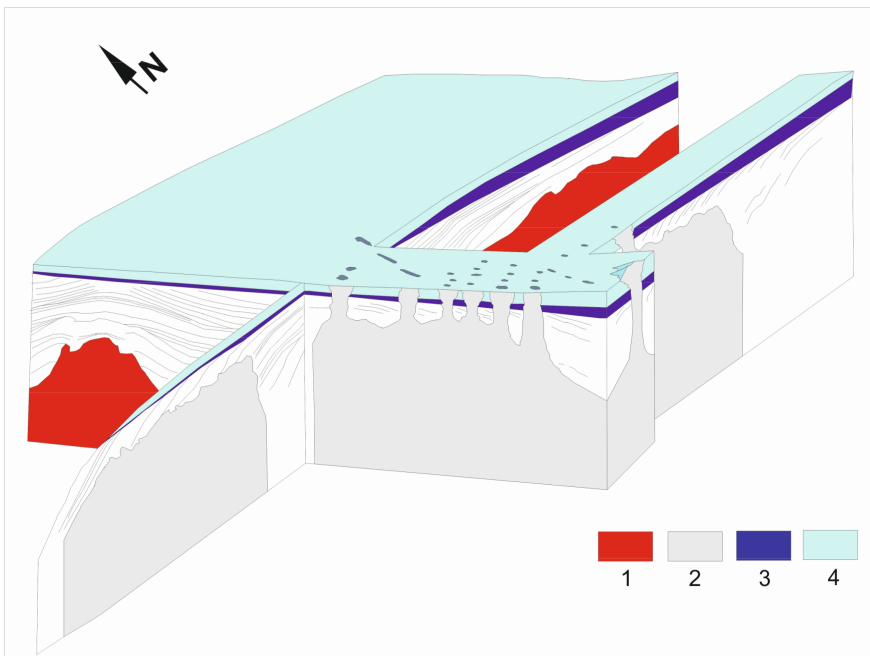

Figure 10. Conduits and pipes located immediately below the outer shelf pockmark field are sourced by a deeper fluid/gas pocket, with a main E-W trending direction. The morphology of the fluids' front depicts sharp and distinct lateral flanks and an irregular top profile arranged in a saw-toothed configuration; (1) volcanics, (2) acoustic turbidity front, (3) deposits related to the latest sea level rise, occurring from $18 \mathrm{ka} \mathrm{BP}$ to $5 \mathrm{ka} \mathrm{BP}$, and (4) present-day highstand muddy deposits.

\subsection{Biogenic Gas or Hydrothermal Venting?}

Amplitude anomalies reveal the boundaries of the detected turbidity pocket along the geologic pile. This suggests abrupt or more gradual variations in acoustic waves velocity, in function of the spatial distribution and concentrations of fluids [73], which is dependent on temperature, pressure, and on the medium permeability [5]. Accumulation of fluids may also have resulted from cross-stratal migration processes, which can occur through faults, intrusive bodies, permeable beds and pipe-like structures [74]. Presently, a true and unambiguous identification of the type, source, and concentration of fluids based on seismic features is not straightforward.

In this study, two distinct fronts with reflection amplitude anomalies and acoustic blanking are compared. The first was located in the inner shelf and consisted in a total acoustic blanking below a stratigraphic reflector of $\mathrm{U} 1$ in the first sub-bottom of the prodelta area, down to $50 \mathrm{~m}$ b.s.l. The acoustic blanking was characterized by sub-vertical sharp lateral boundaries, delimiting a sub-circular region centred off the Volturno River mouth. A comparison of this acoustic facies with others HR profiles suggests that such a process could have been induced by the occurrence of subsurface biogenic methane, pervasive to the sedimentary environment (submarine delta lobes) and produced in situ by an almost syndepositional degradation of organic compound [21].

The second turbidity front was located at the shelf-to-slope transition area, where lateral distinct boundaries delimited a region in which a diffusive acoustic attenuation of reflections was observed, marked at the top by enhanced reflections arranged in a saw-toothed profile. Such strong impedance contrast could have been driven by the lithology of the depositional sequences building blocks $[6,11,24]$ and thus was related to permeability: fluids migrating into coarser grained sediments seem to produce bubbles which scatter the sound and produce high amplitude reflectors [21]. The saw-toothed profile was revealed by enhanced reflection outlines of the top boundary of several sub-units within U7 up to U5, which were characterized by a pronounced progradational stacking patterns. The lateral and vertical stacking of coarsening-upward sub-units of the outer margin succession [6] accounted for abrupt variations in permeability along the sedimentary pile, driving the formation of fluids-saturated horizons. The mapping of this front revealed a WNW-ESE trending direction, likewise the volcanic structure (U9). A pockmark field was observed above it at the seabed, directly linked to the deep acoustic turbidity pocket (Figure 7a). Hydrothermal fluids usually come from devolatilization processes and have been frequently observed in other volcanic continental margins [75]. 
Thus, below the laterally extensive gas pocket, a magmatic body should have triggered the venting structures. This suggests that such bodies may have followed an E-W trend, potentially correlating to the main direction of normal to oblique faults active during the Quaternary period [35,40,76-78]. A recent study [79] demonstrated the presence of an active hydrothermal system in the onshore sector, corroborating our hypothesis of hydrothermal pumping.

\subsection{Coastal Evolution}

The facies distribution and the spatial organization of the shallow marine depocentres reflect the morpho-dynamicity of coastal sectors along clastic coasts. The elaboration of two isopach maps representing, respectively, the paralic/deltaic and marine lithosomes (U3 and U2) composing the transgressive wedge, enabled observations on the depocentres modifications, which occurred during the latest sea level rise (Figure 11). As reported for similar deposits all over the world, we assisted with a general shore retreat and a main landward shift of the coastal systems $[15,57,80-83]$. Furthermore, a southward migration of the river mouth, as suggested by the different distribution of the shallow-marine depocentres (U2) with respect to the paralic/deltaic ones (U3), suggests channel mobility processes at the river mouth. Two main depocentres, NE-SW oriented, bounding a relative high, were observed by the 3D-like modelling of the U3 units. On the contrary, the thickness distribution of the marine sub-units (U2) reflected the presence of one main axis with the same direction perpendicular to the coast; in this case, shifted southwards.

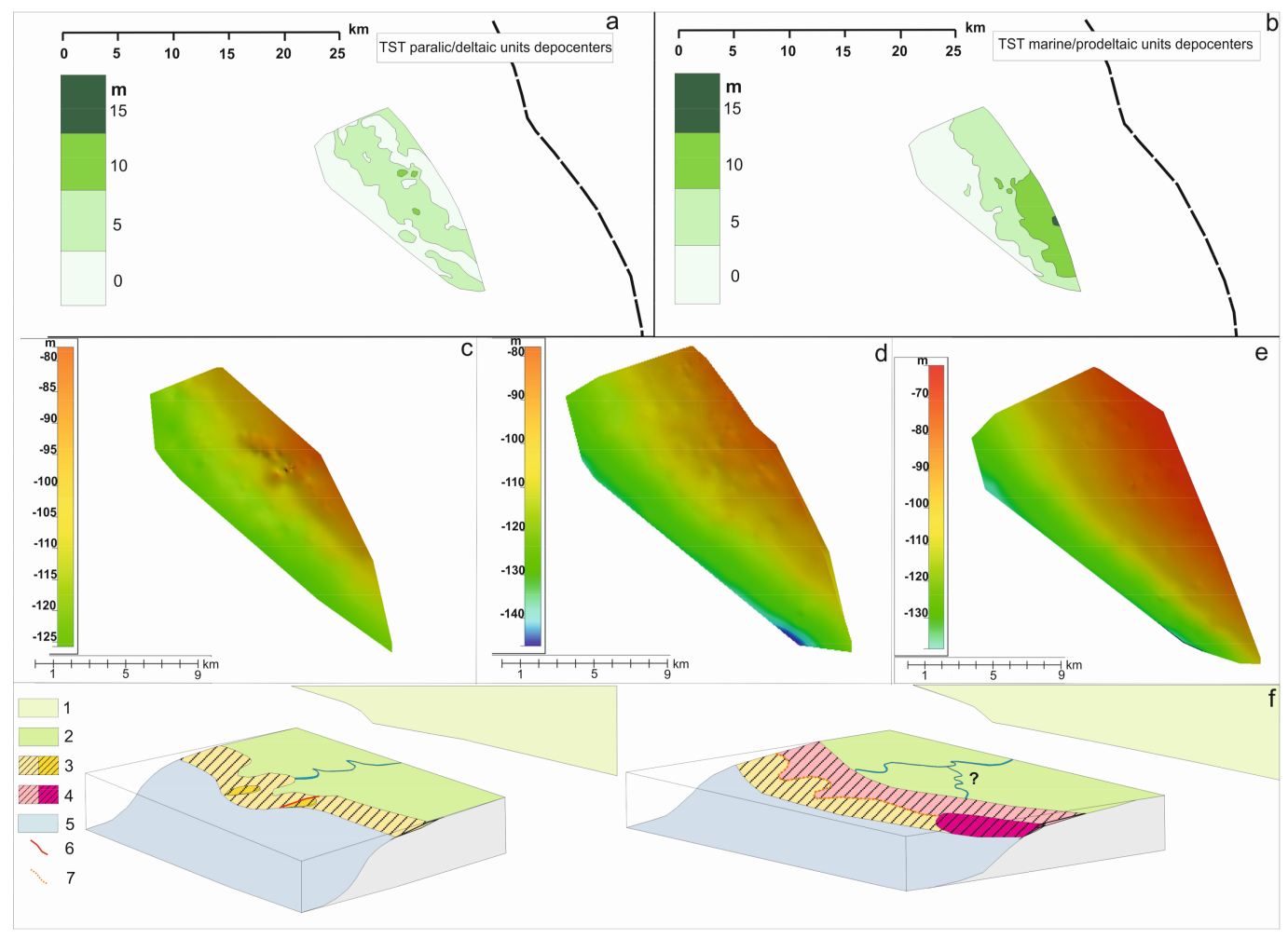

Figure 11. (a) Isopach map of the transgressive paralic/deltaic sub-unit; (b) isopach map of the transgressive shallow marine/prodeltaic sub-unit; (c) surface of the LGM erosional surface (H1); (d) H2 surface bounding the paralic from the shallow marine deposits of the Upper Pleistocene-Holocene transgressive systems tract; (e) top of the transgressive systems tract; and (f) two-step model (qualitative) of the depositional systems shift during transgression (Stage 1 is on the left and Stage 2 is on the right of the figure); 1, present-day coastline and plain (the present day location of the Volturno River mouth is at the seaward bulge of the coast); 2, palaeo-delta plain; 3, paralic/deltaic deposits (U3): in dark yellow, the location of the detected paralic depocentres; 4, shallow marine deposits (U2): in dark rose, the location, slightly shifted southward of the main marine depocentres; 5 , slope area; 6 , fault controlling the settlement of paralic/deltaic deposits; and 7, paleo-coastline location (not to scale). 
Avulsion processes could be induced by different factors, including tectonics, differences in substrate lithologies, and channel progressive infilling [84,85]. As mentioned above, the soft and distributed fault linkages might have controlled the distribution of the paralic/deltaic sub-units at the edge of the developing relative topographic high (Figure 5b). An increased sediment yield and intense reworking of the coastal environment, probably driven by high volcanoclastic supply during volcanic paroxysm, almost coeval to the post-glacial initial stage sea level rise, has been reported in the literature $[7,28]$. The combined effect of a relatively uplifting central area with a strong input in sedimentation probably induced a decrease in the accommodation space in that sector, forcing avulsion processes. We also propose an evolutionary model showing the disposition of the main modelled transgressive depocentres (Figure 11). During Stage 1 (Figure 11a), the deformation of the acoustic substratum accounted for the maximal thickness of the paralic/deltaic lobe in the northern sector of the studied area in a NE-SW trending direction perpendicular to the coast. In Stage 2 (Figure 11b), the delta front started to be shaped by erosional processes after the lowering of the tectonic activity and a new site, shifted southward, became the favourable substrate to accommodate the shallow marine deposition.

\section{Conclusions}

The late Quaternary evolution of the northern Campania continental shelf was affected by the emplacement of magmatic bodies, degassing features, and minor faulting. Small-scale deformations defined a structure characterized by two opposite-facing sets of faults, separated by a relative topographic high located in the overstepping region, about $11.4 \mathrm{~km}$ off the Volturno river mouth. Outward facing NW-SE and ENE-WSW opposite-dipping normal faults identified a structural horst, controlling in extension the transgressive units, as testified by the locally observed growth pattern of the paralic/deltaic transgressive bodies, referring to the initial stages of the latest sea-level rise. The interbasinal ridge, displayed as a belt at the overlapping fault systems terminations, described a roughly E-W oriented zone, accommodating the deformations. We followed the definition proposed in the literature [67] of accommodation zones as structures in regions of overlaps between separated systems of faults as well as accommodating deformations. We also used the geometrical classification proposed by the authors for such zones, interpreting the observed deformational pattern as the result of what should correspond to a small scale antithetic oblique synclinal accommodation zone-like type. Systems of NW-SE and ENE-WSW faults which define the structure should correspond to fault planes reactivated in a different kinematic context, as revealed by their trending direction as well as match the orientation of the most important discontinuities controlling the Tertiary to Quaternary evolution of the area $[31,33,35]$.

Major late Quaternary NW-SE normal faults with quite modest displacements have been reported by several authors $[30,33,35]$. The accommodation zone, individuated by a roughly E-W-oriented relative high, has a slightly oblique orientation with respect to the NE-SW extension trending direction, revealed by the main NNW-SSE trending set of faults and as reported by data from the literature $[33,35]$. The Campi Flegrei caldera collapse, as a major dramatic event occurring at about 15 ka $[41,50]$, should have locally perturbed and rearranged the stress field distribution. Evidence of such a process also could be identified in the renewed location of deposition of the shallow marine transgressive deposits when compared to the position of the paralic transgressive lobes. The combined effect of a relatively uplifting central area with a strong input in sedimentation probably induced a decrease in the accommodation space in that sector, possibly forcing the shallow marine depocentres to shift southwards.

The degassing features, displayed by seismic sections as vertically stacked amplitude anomalies affecting the late Quaternary outer shelf units, coincide with pockmark fields at the seafloor, distributed along an ESE-WNW trending direction and interpreted as the superficial response of a deeper laterally extensive acoustic turbidity front with the same striking direction. This laterally extensive fluids pocket, marked by distinct lateral fronts and an irregular top boundary and arranged in a peculiar saw-toothed 
configuration, was probably controlled by sharp variations in the permeability of outer shelf succession. The main trending direction of this front is similar to the one observed for the buried volcanic body [37,60], resulting in an E-W-trending flat-topped edifice. Magmatic bodies trigger thermal effects on the hosting sedimentary sequences and produce the expulsion of pore-water volumes [86-88]. This observation suggests that the observed fluid front is a hydrothermal-related feature.

Acknowledgments: This work was realized thanks to the National Operation Program-I-AMICA 2013, a project in which CNR-IAMC acquired the high resolution seismic and morpho-bathymetric dataset used here. This study also benefited from the contribution of the RITMARE Flagship Project, funded by MIUR (NRP 2011-2013). We are grateful to Domenico Cosentino and three anonymous reviewers for their stimulating and constructive suggestions.

Author Contributions: Martina Misuraca and Francesca Budillon conceived and developed the study; Sara Innangi, Gabriella Di Martino and Renato Tonielli performed the acquisitions and processed the geophysical data set; Luciana Ferraro was the coordinator of the I-AMICA monitoring activities performed in the studied area; and Martina Misuraca interpreted the seismic sections and wrote the paper.

Conflicts of Interest: The authors declare no conflict of interest. The founding sponsors had no role in the design of the study, in the analyses, or interpretation of data, in the writing of the manuscript, or in the decision to publish the results.

\section{References}

1. Holbrook, J.; Schumm, S.A. Geomorphic and sedimentary response of rivers to tectonic deformation: A brief review and critique of a tool for recognizing subtle epeirogenic deformation in modern and ancient settings. Tectonophysics 1999, 385, 286-306. [CrossRef]

2. Aslan, A.; Autin, W.J.; Blum, M.D. Causes of river avulsion: Insights from the late Holocene avulsion history of the Mississippi River, USA. J. Sediment. Res. 2005, 75, 650-664. [CrossRef]

3. Durán, R.; García-Gil, S.; Diez, R.; Vilas, F. Stratigraphic framework of gas accumulations in the Ría de Pontevedra. Geo-Mar. Lett. 2007, 27, 77-88. [CrossRef]

4. Mazumdar, A.; Peketi, A.; Dewangan, P.; Badesab, F.; Ramprasad, T.; Ramana, M.V.; Patil, D.J.; Dayal, A. Shallow gas charged sediments off the Indian west coast: Genesis and distribution. Mar. Geol. 2009, 267, 71-85. [CrossRef]

5. Chun, J.H.; Ryu, B.J.; Lee, C.S.; Kim, Y.J.; Choi, J.Y.; Kang, N.K.; Bahk, J.J.; Kim, J.H.; Kim, K.J.; Yoo, D.G. Factors determining the spatial distribution of gas-charged sediments in the continental shelf off southeastern Korea. Mar. Geol. 2012, 332-334, 27-39. [CrossRef]

6. Chiocci, F.L. Depositional response to Quaternary fourth-order sea-level fluctuations on the Latium margin (Tyrrhenian Sea, Italy). In Sedimentary Response to Forced Regressions; Hunt, D., Gawthorpe, R.L., Eds.; Geological Society, London, Special Publications: London, UK, 2000; Volume 172, pp. 271-289, ISBN 1862390630.

7. Iorio, M.; Capretto, G.; Petruccione, E.; Marsella, E.; Aiello, G.; Senatore, M.S. Multi-proxy analysis in defining sedimentary processes in very recent prodelta deposits: The Northern Phlegraean offshore example (Eastern Tyrrhenian Margin). Rend. Lincei-Sci. Fis. Nat. 2014, 25, 237-254. [CrossRef]

8. Sacchi, M.; Insinga, D.; Milia, A.; Molisso, F.; Raspini, A.; Torrente, M.; Conforti, A. Stratigraphic signature of the Vesuvius 79 AD event off the Sarno prodelta system, Naples Bay. Mar. Geol. 2005, 222-223, 443-469. [CrossRef]

9. Budillon, F.; Senatore, M.R.; Insinga, D.D.; Iorio, M.; Lubritto, C.; Roca, M.; Rumolo, P. Late Holocene sedimentary changes in shallow water settings: the case of the Sele river offshore in the Salerno Gulf (south-eastern Tyrrhenian Sea, Italy). Rend. Lincei-Sci. Fis. Nat. 2012, 23, 25-43. [CrossRef]

10. Imbrie, J.; Hays, J.D.; Martinson, D.G.; McIntyre, A.; Mix, A.C.; Morley, J.J.; Pisias, N.G.; Prell, W.L.; Shackleton, N.J. The orbital theory of Pleistocene climate: Support from a revised chronology of the marine d18O record. In Milankovitch and Climate; Berger, A., Imbrie, J., Hays, J.D., Kukla, G., Saltzman, B., Eds.; D. Reidel: Dordrecht, The Netherlands, 1984; Part 1; pp. 289-305.

11. Posamentier, H.W.; Allen, G.P. Variability of the sequence stratigraphic model: Effects of local basin factors. Sediment. Geol. 1993, 86, 91-109. [CrossRef]

12. Swift, D.J.P. Coastal erosion and transgressive stratigraphy. J. Geol. 1968, 76, 444-456. [CrossRef] 
13. Cattaneo, A.; Steel, R.J. Transgressive deposits: A review of their variability. Earth Sci. Rev. 2003, 62, 187-228. [CrossRef]

14. Catuneanu, O.; Abreu, V.; Bhattacharya, J.P.; Blum, M.D.; Dalrymple, R.W.; Eriksson, P.G.; Winker, C. Towards the standardization of sequence stratigraphy. Earth Sci. Rev. 2009, 92, 1-33. [CrossRef]

15. Smith, L.; Forster, C.; Evans, J. Interaction of fault zones, fluid flow, and heat transfer at the basin scale. In Hydrogeology of Low Permeability Environments: From a Special Symposium at the 28th International Geological Congress, Washington, DC, USA, 9-19 July 1989; Neuman, S.P., Neretnieks, I., Eds.; Hydrogeology; Verlag Heinz Heise: Hanover, Germany, 1990; Volume 2, pp. 41-67, ISBN 3-922705-61-8.

16. Caine, J.S.; Evans, J.P.; Forster, C.B. Fault zone architecture and permeability structure. Geology 1996, 24, 1025-1028. [CrossRef]

17. Norton, D.; Knapp, R. Transport phenomena in hydrothermal systems: The nature of porosity. Am. J. Sci. 1977, 22, 913-936. [CrossRef]

18. Henley, R.W.; Adams, D.P.M. Strike-slip fault reactivation as a control on epithermal vein-style gold mineralization. Geology 1992, 20, 443-446. [CrossRef]

19. Andresen, K.J. Fluid flow features in hydrocarbon plumbing systems: What do they tell us about the basin evolution? Mar. Geol. 2012, 332-334, 89-108. [CrossRef]

20. Hustoft, S.; Bunz, S.; Mienert, J. Three-dimensional seismic analysis of the morphology and spatial distribution of chimneys beneath the Nyegga pockmark field, offshore mid-Norway. Basin Res. 2010, 22, 465-480. [CrossRef]

21. Judd, A.G.; Hovland, M. Seabed Fluid Flow: The Impact on Geology, Biology and the Marine Environment; University Press: Cambridge, UK, 2007; 475p, ISBN 9781139461603.

22. Martínez-Carreño, N.; García-Gil, S. The Holocene gas system of the Ría de Vigo (NWSpain): Factors controlling the location of gas accumulations, seeps and pockmarks. Mar. Geol. 2013, 344, 82-100. [CrossRef]

23. Chappell, J.; Shackleton, N.J. Oxygen isotopes and sea level. Nature 1986, 324, 137-140. [CrossRef]

24. Hunt, D.; Tucker, M.E. Stranded parasequences and the forced regressive wedge systems tract: Deposition during base-level fall. Sediment. Geol. 1992, 81, 1-9. [CrossRef]

25. Amore, F.O.; Ciampo, G.; Di Donato, V.; Esposito, P.; Pennetta, M.; Russo Ermolli, E.; Staiti, D.; Valente, A. A multidisciplinary study of Late Pleistocene-Holocene sediments of the Gaeta bay continental shelf. Il Quaternario 1996, 9, 521-532.

26. Coppa, M.G.; Ferraro, L.; Pennetta, M.; Russo, B.; Valente, A.; Secchione, C. Sedimentology and micropaleontology of the core G39-C27 (Gaeta bay, central Tyrrhenian Sea, Italy). Il Quaternario 1996, 9, 687-696.

27. Aiello, G.; Marsella, E.; Sacchi, M. Quaternary structural evolution of the Terracina and Gaeta basins (Eastern Tyrrhenian margin, Italy). Rend. Lincei-Sci. Fis. Nat. 2000, 11, 41-58. [CrossRef]

28. Aiello, G.; Insinga, D.D.; Iorio, M.; Meo, A.; Senatore, M.R. On the occurrence of the Neapolitan Yellow Tuff tephra in the Northern Plegraean Fields offshore (Eastern Tyrrhenian margin; Italy). Ital. J. Geosci. 2017, 136. [CrossRef]

29. Shackleton, N.J. Oxygen isotopes, ice volume and sea level. Quat. Sci. Rev. 1987, 6, 183-190. [CrossRef]

30. Milia, A.; Torrente, M.M. Late Quaternary volcanism and transtensional tectonics in the Bay of Naples, Campanian continental margin, Italy. Miner. Petrol. 2003, 79, 49-65. [CrossRef]

31. Moussat, E.; Rehault, J.P.; Fabbri, A. Rifting et évolution tectono-sédimentaire du Bassin Tyrrhénien au cours du Néogène et du Quaternaire. G. Geol. Ser. 1986, 48, 41-62.

32. Sartori, R. The main results of ODP Leg 107 in the frame of Neogene to Recent geology of the Peri-Tyrrhenian areas. In Proceedings of ODP, Scientific Results; Kastens, A., Mascle, K.J., Eds.; Ocean Drilling Program: College Station, TX, USA, 1990; Volume 107, pp. 715-730.

33. Hippolyte, J.C.; Angelier, J.; Roure, F. A major geodynamic change revealed by Quaternary stress pattern in the Southern Apennines. Tectonophysics 1994, 230, 199-210. [CrossRef]

34. Cinque, A.; Patacca, E.; Scandone, P.; Tozzi, M. Quaternary kinematic evolution of the Southern Apennines. Annali Geofisica 1993, 36, 249-260.

35. Caiazzo, C.; Ascione, A.; Cinque, A. Late Tertiary-Quaternary tectonics of the Southern Apennines (Italy): New evidences from the Tyrrhenian slope. Tectonophysics 2006, 421, 23-51. [CrossRef]

36. Milia, A. Aggrading and prograding infill of a peri-Tyrrhenian Basin (Naples Bay, Italy). Geo-Mar. Lett. 1999, 19, 237-244. [CrossRef] 
37. Milia, A.; Torrente, M.M.; Massa, B.; Iannace, P. Possible changes in rifting directions in the Campania margin (Italy): New constrains for the Tyrrhenian sea opening. Glob. Planet. Chang. 2013, 109, 3-17. [CrossRef]

38. Romano, P.; Santo, A.; Voltaggio, M. L'evoluzione geomorfologica della pianura del F. Volturno (Campania) durante il tardo Quaternario (Pleistocene medio-superiore-Olocene). Il Quaternario 1994, 7, 41-56.

39. Amato, V.; Aucelli, P.P.C.; Cinque, A.; D’Argenio, B.; Di Donato, V.; Russo Ermolli, E.; Pappone, G.; Petrosino, P.; Rosskopf, C.M. Holocene palaeo-geographical evolution of the Sele river coastalplain (Southern Italy): New morpho-sedimentary data from the Paestum area. IL Quaternario 2011, 24, 5-7.

40. Torrente, M.M.; Milia, A.; Bellucci, F.; Rolandi, G. Extensional tectonics in the Campania Volcanic Zone (eastern Tyrrhenian Sea, Italy): New insights into the relationship between faulting and ignimbrite eruptions. Ital. J. Geosci. 2010, 129, 297-315.

41. Rosi, M.; Sbrana, A. Phlegrean Fields; CNR, Quaderni Ricerca Scientifica: Rome, Italy, 1987; Volume 9, 176p.

42. De Vivo, B.; Rolandi, G.; Gans, P.B.; Calvert, A.; Bohrson, W.A.; Spera, F.J.; Belkin, H.E. New constraints on the pyroclastic eruptive history of the Campanian volcanic plain (Italy). Mineral. Petrol. 2001, 73, 47-65. [CrossRef]

43. Milia, A.; Torrente, M.M. Fold uplift and syn-kinematic stratal architectures in a region of active transtensional tectonics and volcanism, Eastern Tyrrhenian Sea. Geol. Soc. Am. Bull. 2000, 112, 733-747. [CrossRef]

44. Acocella, V.; Faccenna, C.; Funiciello, R. Elementi strutturali della media Valle Latina. Boll. Soc. Geol. Ital. 1996, 115, 501-518.

45. De Rita, D.; Giordano, G. Volcanological and structural evolution of Roccamonfina volcano (Italy): Origin of the summit caldera. In Volcano Instability on the Earth and Other Planets; McGuire, W.J., Jones, A.P., Neuberg, J., Eds.; Geological Society Special Publications: London, UK, 1996; Volume 110, pp. 209-224.

46. De Rita, D.; Funiciello, R.; Pantosti, D.; Salvini, F.; Sposato, A.; Velonà, M. Geological and structural characteristics of the Pontine Islands (Italy) and implications with the evolution of the Tyrrhenian margin. Mem Soc. Geol. Ital. 1986, 36, 55-65.

47. Di Brozolo, F.R.; Di Girolamo, P.; Turi, B.; Oddone, M. 40Ar-39Ar e K-Ar dating of K-rich rocks from the Roccamonfina Volcano, Roman Comagmatic Region, Italy. Geochim. Cosmochim. Acta 1988, 52, 1435-1441. [CrossRef]

48. Torrente, M.M.; Milia, A. Volcanism and faulting of the Campania margin (Eastern Tyrrhenian Sea, Italy): A three-dimensional visualization of a new volcanic field off Campi Flegrei. Bull. Volcanol. 2013, 75, 1-13. [CrossRef]

49. Di Girolamo, P.; Ghiara, M.R.; Lirer, L.; Munno, R.; Rolandi, G.; Stanzione, D. Vulcanologia e petrologia dei Campi Flegrei. Boll. Soc. Geol. Ital. 1984, 103, 349-413.

50. Deino, A.L.; Orsi, G.; Piochi, M.; de Vita, S. The age of the Neapolitan Yellow Tuff caldera-forming eruption (Campi Flegrei caldera-Italy) assessed by 40Ar/39Ar dating method. J. Volcanol. Geotherm. Res. 2004, 133, 157-170. [CrossRef]

51. Bigi, G.; Cosentino, D.; Parotto, M.; Sartori, R.; Scandone, P. Structural Model of Italy; Scale 1:500,000; Quaderni de "La Ricerca Scientifica"; Consiglio Nazionale delle Ricerche (CNR): Firenze, Italy, 1992.

52. Ferraro, L.; Giordano, L.; Iengo, A.; Bonomo, S.; Cascella, A.; Di Martino, G.; Innangi, S.; Tonielli, R.; Gherardi, S.; Tamburrino, S.; et al. Experiences of integrated monitoring of a marine-coastal area: The Volturno River mouth. Quad. Geofis. 2017, 146, 1-70.

53. Innangi, S.; Barra, M.; Di Martino, G.; Parnum, I.M.; Tonielli, R.; Mazzola, S. Reson SeaBat 8125 backscatter data as a tool for seabed characterization (Central Mediterranean, Southern Italy): Results from different processing approaches. Appl. Acoust. 2015, 87, 109-122. [CrossRef]

54. Margaritelli, G.; Vallefuoco, M.; Di Rita, F.; Capotondi, L.; Bellucci, L.G.; Insinga, D.D.; Petrosino, P.; Bonomo, S.; Cacho, I.; Cascella, A.; et al. Marine response to climate changes during the last five millennia in the central Mediterranean Sea. Glob. Planet. Chang. 2016. [CrossRef]

55. Patruno, S.; Hampson, G.J.; Jackson, C.A.-L. Quantitative characterisation of deltaic and subaqueous clinoforms. Earth Sci. Rev. 2015, 142, 79-119. [CrossRef]

56. Chiocci, F.L.; Casalbore, D. Submarine gullies on Italian upper slopes and their relationship with volcanic activity revisited 20 years after Bill Normark's pioneering work. Geosphere 2011, 7, 1284-1293. [CrossRef]

57. Amorosi, A.; Pacifico, A.; Rossi, V.; Ruberti, D. Late Quaternary incision and deposition in an active volcanic setting: The Volturno valley fill, southern Italy. Sediment. Geol. 2012, 282, 307-320. [CrossRef] 
58. Lobo, F.J.; Tesson, M.; Gensous, B. Stratal architectures of late Quaternary regressive transgressive cycles in the Roussillon Shelf (SW Gulf of Lions, France). Mar. Pet. Geol. 2004, 21, 1181-1203. [CrossRef]

59. Grant, K.M.; Rohling, E.J.; Bar-Matthews, M.; Ayalon, A.; Medina-Elizalde, M.; Bronk Rampsey, C.; Satow, C.; Roberts, A.P. Rapid coupling between ice volume and polar temperature over the past 150,000 years. Nature 2012, 491, 745-747. [CrossRef] [PubMed]

60. De Alteriis, G.; Fedi, M.; Passaro, S.; Siniscalchi, A. Magneto-seismic interpretation of subsurface volcanism in the Gaeta Gulf (Italy, Tyrrhenian Sea). Ann. Geophys. 2006, 49, 929-943.

61. Gibbs, A.D. Structural evolution of extensional basin margins. J. Geol. Soc. 1984, 141, 609-620. [CrossRef]

62. Peacock, D.C.P.; Sanderson, D.J. Geometry and development of relay ramps in normal fault systems. Am. Assoc. Pet. Geol. Bull. 1994, 78, 147-165.

63. Rowland, J.V.; Sibson, R.H. Extensional fault kinematics within the Taupo Volcanic Zone, New Zealand: Soft-linked segmentation of a continental rift system. N. Z. J. Geol. Geophys. 2001, 44, 271-284. [CrossRef]

64. Gawthorpe, R.L.; Hurst, J.M. Transfer zones in extensional basins: Their structural style and influence on drainage development and stratigraphy. J. Geol. Soc. 1993, 150, 1137-1152. [CrossRef]

65. Trudgill, B.; Cartwright, J. Relay-ramp forms and normal-fault linkages, Canyonlands National Park, Utah. Geol. Soc. Am. Bull. 1994, 106, 1143-1157. [CrossRef]

66. Morley, C.K.; Nelson, R.A.; Patton, T.L.; Munn, S.G. Transfer zones in the East African Rift system and their relevance to hydrocarbon exploration in rifts. Am. Assoc. Pet Geol. Bull. 1990, 74, 1234-1253.

67. Faulds, J.E.; Varga, R.J. The role of accommodation zones and transfer zones in the regional segmentation of extended terranes. Geol. Soc. Am. Spec. Pap. 1998, 323, 1-45.

68. Lister, G.S.; Etheridge, M.A.; Symonds, P.A. Detachment faulting and the evolution of passive continental margins. Geology 1986, 14, 246-250. [CrossRef]

69. Walsh, J.J.; Watterson, J. Geometric and kinematic coherence and scale effects in normal fault systems. In The Geometry of Normal Faults; Roberts, A.M., Yielding, G., Freeman, B., Eds.; Geological Society of London Special Publication: London, UK, 1991; Volume 56, pp. 193-206, ISBN 0-903317-59-1.

70. McClay, K.; Khalil, S. Extensional hard linkages, eastern Gulf of Suez, Egypt. Geology 1998, 26, 563-566. [CrossRef]

71. Gay, A.; Lopez, M.; Ondreas, H.; Charlou, J.-L.; Sermondadaz, G.; Cochonat, P. Seafloor facies related to upward methane flux within a Giant Pockmark of the Lower Congo Basin. Mar. Geol. 2006, 226, 81-95. [CrossRef]

72. Pilcher, R.; Argent, J. Mega-pockmarks and linear pockmark trains on the West African continental margin. Mar. Geol. 2007, 244, 15-32. [CrossRef]

73. Wilkens, R.H.; Richardson, M.D. The influence of gas bubbles on sediment acoustic properties: In situ, laboratory, and theoretical results from Eckernförde Bay, Baltic sea. Cont. Shelf Res. 1998, 18, 1859-1892. [CrossRef]

74. Cartwright, J.; Huuse, M.; Aplin, A. Seal bypass systems. AAPG Bull. 2007, 91, 1141-1166. [CrossRef]

75. Trude, J.; Cartwright, J.; Davies, R.J.; Smallwood, J. New technique for dating igneous sills. Geology 2003, 31, 813-816. [CrossRef]

76. Milia, A.; Torrente, M.M. Evoluzione tettonica della Penisola Sorrentina (Margine Peritirrenico Campano). Boll. Soc. Geol. Ital. 1997, 116, 487-502.

77. Bruno, P.P.; Di Fiore, V.; Ventura, G. Seismic study of the '41st parallel' Fault System offshore the Campanian-Latial continental margin, Italy. Tectonophysics 2000, 324, 37-55. [CrossRef]

78. Cuffaro, M.; Martorelli, E.; Bosman, A.; Conti, A.; Bigi, S.; Muccini, F.; Cocchi, L.; Ligi, M.; Bortoluzzi, G.; Scrocca, D.; et al. The Ventotene Volcanic Ridge: A newly explored complex in the central Tyrrhenian Sea (Italy). Bull. Volcanol. 2016, 78, 2-19. [CrossRef]

79. Cuoco, E.; Minissale, A.; Di Leo, A.; Tamburrino, S.; Iorio, M.; Tedesco, D. Fluid geochemistry of the Mondragone hydrothermal systems (southern Italy): Water and gas compositions vs. geostructural setting. Int. J. Earth Sci. 2017, 106, 2429-2444. [CrossRef]

80. Belknap, D.F.; Kraft, J.C. Preservation potential of transgressive coastal lithosomes on the U.S. Atlantic shelf. Mar. Geol. 1981, 42, 429-442. [CrossRef]

81. Trincardi, F.; Correggiari, A.; Roveri, M. Late Quaternary transgressive erosion and deposition in a modern epicontinental shelf: The Adriatic Semi-enclosed Basin. Geo-Mar. Lett. 1994, 14, 41-51. [CrossRef] 
82. Amorosi, A.; Milli, S. Late Quaternary depositional architecture of Po and Tevere river deltas (Italy): A worldwide comparison with coeval deltaic successions. Sediment. Geol. 2001, 144, 357-375. [CrossRef]

83. Storms, J.E.A.; Weltje, G.J.; Terra, G.J.; Cattaneo, A.; Trincardi, F. Coastal dynamics under conditions of rapid sea-level rise: Late Pleistocene to Early Holocene evolution of barrier-lagoon systems on the northern Adriatic shelf (Italy). Quat. Sci. Rev. 2008, 27, 1107-1123. [CrossRef]

84. Miall, A.D. The Geology of Fluvial Deposits; Springer: Berlin/Heidelberg, Germany, 1996.

85. Jones, L.S.; Schumm, S.A. Causes of avulsion: An overview. Spec. Publ. Ass. Sediment 1999, 28, 171-178.

86. Grapes, R.H.; Reid, D.L.; McPherson, J.G. Shallow dolerite intrusions and phreatic eruption in the Allan Hills region, Antarctica. N. Z. J. Geol. Geophys. 1973, 17, 563-577. [CrossRef]

87. Einsele, G. Mechanism of Sill Intrusion into Soft Sediment and Expulsion of Pore Water; Initial Reports for Deep Sea Drilling Project 1982; Geologisches Institut der Universitàt Tubingen: Tubingen, Germany, 1982; pp. 1169-1176.

88. Krynauw, J.R.; Hunter, D.R.; Wilsona, H. Emplacement of sills into wet sediments at Grunehogna, western Dronning Maud Land, Antarctica. J. Geol. Soc. 1988, 145, 1019-1032. [CrossRef]

(C) 2018 by the authors. Licensee MDPI, Basel, Switzerland. This article is an open access article distributed under the terms and conditions of the Creative Commons Attribution (CC BY) license (http://creativecommons.org/licenses/by/4.0/). 